\title{
NOx conversion on LSM15-CGO10 cell stacks with BaO impregnation
}

\author{
Traulsen, Marie Lund; Andersen, Kjeld Bøhm; Kammer Hansen, Kent
}

Published in:

Journal of Materials Chemistry

Link to article, DOI:

10.1039/c2jm31417g

Publication date:

2012

Link back to DTU Orbit

Citation (APA):

Traulsen, M. L., Andersen, K. B., \& Kammer Hansen, K. (2012). NO conversion on LSM15-CGO10 cell stacks with $\mathrm{BaO}$ impregnation. Journal of Materials Chemistry, 22(23), 117ð2-11800.

https://doi.org/10.1039/c2jm31417g

\section{General rights}

Copyright and moral rights for the publications made accessible in the public portal are retained by the authors and/or other copyright owners and it is a condition of accessing publications that users recognise and abide by the legal requirements associated with these rights.

- Users may download and print one copy of any publication from the public portal for the purpose of private study or research.

- You may not further distribute the material or use it for any profit-making activity or commercial gain

- You may freely distribute the URL identifying the publication in the public portal

If you believe that this document breaches copyright please contact us providing details, and we will remove access to the work immediately and investigate your claim 


\title{
$\mathrm{NO}_{\mathrm{x}}$ conversion on LSM15-CGO10 cell stacks with $\mathrm{BaO}$ impregnation
}

\author{
Marie Lund Traulsen,* Kjeld Bøhm Andersen and Kent Kammer Hansen \\ Received (in $X X X, X X X)$ Xth $X X X X X X X X X 20 X X$, Accepted Xth $X X X X X X X X X 20 X X$ \\ DOI: $10.1039 / b 000000 x$
}

${ }_{5}$ The electrochemical conversion of $\mathrm{NO}_{\mathrm{x}}$ on non-impregnated and $\mathrm{BaO}$-impregnated LSM15-CGO10 $\left(\mathrm{La}_{0.85} \mathrm{Sr}_{0.15} \mathrm{MnO}_{3}-\mathrm{Ce}_{0.9} \mathrm{Gd}_{0.1} \mathrm{O}_{1.95}\right)$ porous cell stacks has been investigated, and extensive impedance analysis have been performed to identify the effect of the BaO on the electrode processes. The investigation was conducted in the temperature range $300-500{ }^{\circ} \mathrm{C}$, a polarisation range from $3 \mathrm{~V}$ to $9 \mathrm{~V}$ and in atmospheres containing $1000 \mathrm{ppm} \mathrm{NO}, 1000 \mathrm{ppm} \mathrm{NO}+10 \% \mathrm{O}_{2}$ and $10 \% \mathrm{O}_{2}$. On the non-impregnated cell stacks no $\mathrm{NO}_{\mathrm{x}}$ conversion was observed at any of the investigated conditions. However, $\mathrm{BaO}$ impregnation greatly enhanced the $\mathrm{NO}_{\mathrm{x}}$ conversion and at $400{ }^{\circ} \mathrm{C}$ and ${ }_{10} 9 \mathrm{~V}$ polarisation a BaO-impregnated cell stack showed $60 \% \mathrm{NO}_{\mathrm{x}}$ conversion into $\mathrm{N}_{2}$ with $8 \%$ current efficiency in 1000 ppm $\mathrm{NO}+10 \%$ $\mathrm{O}_{2}$. This demonstrates high $\mathrm{NO}_{\mathrm{x}}$ conversion can be achieved on an entirely ceramic cell without expensive noble metals. Furthermore the $\mathrm{NO}_{\mathrm{x}}$ conversion and current efficiency was shown to be strongly dependent on temperature and polarisation. The impedance analysis revealed that the $\mathrm{BaO}$-impregnation increased the overall activity of the cell stacks, but also changed the adsorption state of $\mathrm{NO}_{\mathrm{x}}$ on the electrodes; whether the increased activity or the changed adsorption state is mainly responsible for the improved $\mathrm{NO}_{\mathrm{x}}$ conversion remains 15 unknown. 


\section{Introduction}

In Europe the $\mathrm{NO}_{\mathrm{x}}$-emission from the road transport has been significantly reduced during the last 10 years, mainly due to the introduction of the three-way-catalyst on gasoline vehicles ${ }^{1}$. Due to the negative impact of $\mathrm{NO}_{\mathrm{x}}$-emissions on both human health and the environment ${ }^{2}$, a further reduction in the $\mathrm{NO}_{\mathrm{x}}$ emissions from the car fleet is desirable. However a major challenge in that connection is the increased number of diesel vehicles, as the conventional three-way-catalyst is incapable of removing $\mathrm{NO}_{\mathrm{x}}$ from diesel exhaust. For this reason much research is currently focused on $\mathrm{NO}_{\mathrm{x}}$-removal technologies for diesel exhaust, the most heavily investigated technologies being selective catalytic reduction with ammonia $\left(\mathrm{NH}_{3}-\mathrm{SCR}\right)$, selective catalytic reduction with hydrocarbons (HC-SCR) and the $\mathrm{NO}_{\mathrm{x}}$-storage and reduction (NSR) catalyst ${ }^{3}$. In all these three technologies there is the need for a reducing agent, either coming from operating the engine occasionally in an excess fuel to air-ratio (HC-SCR and NSR) or supplied by a separate system ( $\mathrm{NH}_{3}$-SCR). A $\mathrm{NO}_{\mathrm{x}}$ removal technology without the need for the addition of a reducing agent would be simpler and therefore advantageous compared to the aforementioned technologies.

A suggestion for such a technology is electrochemical $\mathrm{NO}_{\mathrm{x}}$ removal, where the $\mathrm{NO}_{\mathrm{x}}$ is reduced to $\mathrm{N}_{2}$ and $\mathrm{O}_{2}$ by electrons supplied to a polarised electrode ${ }^{4}$. The technology is inspired by the finding in 1975 by Pancharatnam et al. ${ }^{5}$ that NO can be reduced to $\mathrm{N}_{2}$ during polarisation of a zirconia based cell in the absence of oxygen, and later it was shown by Cicero et al. ${ }^{6}$ and Hibino et al. ${ }^{7}$ that $\mathrm{NO}_{\mathrm{x}}$ also could be electrochemically reduced in the presence of oxygen. Since then several studies has been made in the field of electrochemical deNO $\mathrm{x}_{\mathrm{x}}$ by different research groups ${ }^{6-13}$. For electrochemical $\mathrm{NO}_{\mathrm{x}}$ removal to become a technology of practical interest, a first and major obstacle to be overcome is to find electrode materials with a sufficiently high activity and selectivity for $\mathrm{NO}_{\mathrm{x}}$ reduction ${ }^{4}$.

With respect to selectivity the major problem is the competing reduction of $\mathrm{O}_{2}$; in eq. 1 the desired NO reduction on the cathode is stated and the competing $\mathrm{O}_{2}$ reduction is stated in Eq. 2.

$$
\begin{aligned}
& \mathrm{NO}+2 \mathrm{e}^{-} \rightarrow \frac{1}{2} \mathrm{~N}_{2}+\mathrm{O}^{2-} \\
& \frac{1}{2} \mathrm{O}_{2}+2 \mathrm{e}^{-} \rightarrow \mathrm{O}^{2-}
\end{aligned}
$$

In this work it is investigated if the conversion of $\mathrm{NO}_{\mathrm{x}}$ at 300$500{ }^{\circ} \mathrm{C}$ on LSM15-CGO10 composite electrodes can be increased by impregnating the electrodes with $\mathrm{BaO}$. $\mathrm{BaO}$ is the most commonly used $\mathrm{NO}_{\mathrm{x}}$ storage compound in the NSR catalyst ${ }^{14}$, and the idea in this work is to increase the $\mathrm{NO}_{\mathrm{x}}$ conversion by up-concentrating the $\mathrm{NO}_{\mathrm{x}}$ on the electrode surface in the form of $\mathrm{Ba}\left(\mathrm{NO}_{3}\right)_{2}$. Previous work by $\mathrm{Li}$ et al. ${ }^{15}$ and Yoshinobu et al. ${ }^{16}$ have shown good results from combining $\mathrm{BaO}$ and electrochemical deNO $\mathrm{N}_{\mathrm{x}}$, but in both cases the investigated electrode systems contained Pt or other noble metals, which increases the cost of the system. The work by Simonsen et al. ${ }^{17}$ showed LSM15 in combination with Ba could be an efficient catalyst for electrochemical $\mathrm{NO}_{\mathrm{x}}$ removal; however the work did not include any conversion measurements. Conversion measurements are included in this work, where electrochemical $\mathrm{NO}_{\mathrm{x}}$ removal is investigated on an entirely ceramic system, i.e. a system without expensive noble metals. LSM15 is chosen as electrode material for this investigation, as LSM15 has good stability compared to other perovskites like $\mathrm{La}_{1-\mathrm{x}} \mathrm{Sr}_{\mathrm{x}} \mathrm{Fe}_{1-\mathrm{y}} \mathrm{Co}_{\mathrm{y}} \mathrm{O}_{3}$ and $\mathrm{Ba}_{1-\mathrm{x}} \mathrm{Sr}_{\mathrm{x}} \mathrm{Fe}_{1-\mathrm{y}} \mathrm{Co}_{\mathrm{y}} \mathrm{O}_{3}$, eventhough these have a higher activity in the investigated temperature range ${ }^{18}$. CGO10 was chosen as electrolyte and component in the electrode, as the ionic conductivity of CGO10 is superior to the ionic conductivity of YSZ (Yttria Stabilized Zirconia) below $600{ }^{\circ} \mathrm{C}^{19}$. The non-impregnated and $\mathrm{BaO}-$ impregnated electrodes were investigated in a set-up with a porous 11-layer cell stack, as the large contact area between gas flow and cell stack in this set-up increases the conversion and makes it easy to detect any changes in the gas composition. Two complementary approaches were used to investigate the effect of the $\mathrm{BaO}$-impregnation on the electrode performance. The one approach involved measurements of the $\mathrm{NO}_{\mathrm{x}}$ conversion as function of temperature, polarisation and gas composition. This approach was supplemented by an extensive impedance analysis aimed at clarifying which processes contributed to the polarisation resistance of the cell stacks, and how these processes were affected by the $\mathrm{BaO}$ impregnation.

\section{Experimental:}

\section{Cell stack fabrication:}

The 11-layer porous cell stacks consisted of 11 alternating layers of composite electrode (65 wt\% LSM15 (Haldor Topsøe) and $35 \mathrm{wt} \%$ CGO10 (Rhodia)) and electrolyte (CGO10). The porous composite electrode layers were manufactured by mixing LSM15, CGO10, solvent (mixture of ethanol and butanone), binder (polyvinylbuyral), dispersant (polyvinylpyrrolidone) and pore former (graphite) into a slurry, ball mill the slurry and thereafter tape caste the slurry into green tapes of approximately $40 \mu \mathrm{m}$ thickness, for more details see Hee et al ${ }^{20}$. The porous CGO10 layers were prepared in a similar manner, and subsequent the green electrode and electrolyte layers were laminated together and round cell stacks were stamped out. The cell stacks were sintered with the 
maximum temperature $1250{ }^{\circ} \mathrm{C}$ held for 4 hours and thereby achieved a diameter of $\approx 14 \mathrm{~mm}$. Prior to mounting in the testsetup the cell stacks were painted with gold paste (ESL ElectroScience) mixed with $20 \%$ carbon (Graphit Kropfmühl AG), which was burned off at $800{ }^{\circ} \mathrm{C}$ in order to create porous gold current collectors on each side of the cell stack.

\section{Impregnation}

For impregnation of the porous cell stacks with $\mathrm{BaO}$ a $0.3 \mathrm{M}$ aqueous $\mathrm{Ba}\left(\mathrm{NO}_{3}\right)_{2}$ (Merck) solution with $10 \mathrm{wt} \% \mathrm{P} 123$ (BASF) was prepared. The cell stacks were covered with the $\mathrm{Ba}\left(\mathrm{NO}_{3}\right)_{2}$ solution and put under vacuum for $\approx 10 \mathrm{~s}$, whereafter excess impregnation solution was wiped of the surface. The impregnated cell stacks were then heated to $700{ }^{\circ} \mathrm{C}$ for $1 \mathrm{~h}$ to decompose the $\mathrm{Ba}\left(\mathrm{NO}_{3}\right)_{2}$ into $\mathrm{BaO} .700{ }^{\circ} \mathrm{C}$ was chosen to assure total

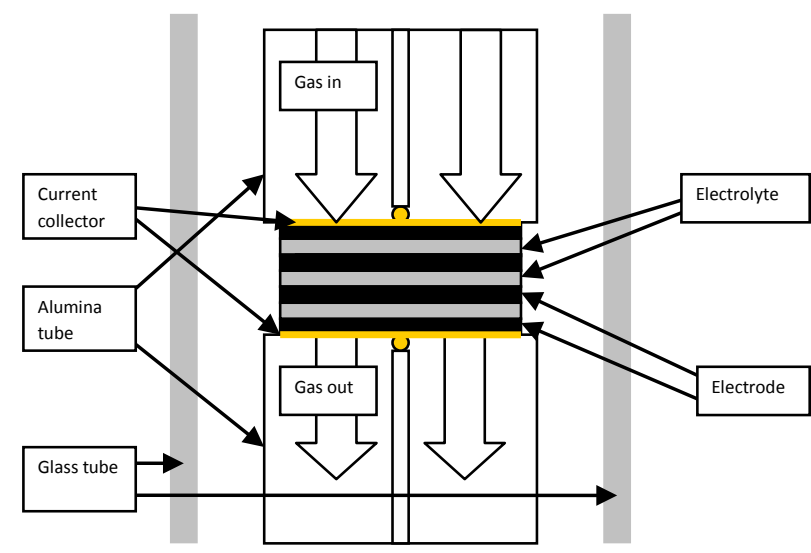

Fig. 1 Sketch of test-setup for porous 11-layer cell stack. Reprinted with permission from Werchmeister et al. $2010^{13}$

decomposition, since a DTA experiments showed $\mathrm{Ba}\left(\mathrm{NO}_{3}\right)_{2}$ decomposed at $600-640^{\circ} \mathrm{C}$, even though the decomposition temperature reported by literature in general were lower, in the range $500-600{ }^{\circ} \mathrm{C}^{21-23}$.

\section{Test-setup}

For electrochemical cell testing the stack was mounted in between two alumina tubes, which contained channels for the gas flow and measurement probes for the electrochemical characterization. The cell and the alumina tubes were inclosed in a quartz tube and mounted vertically in a furnace. A sketch of the set-up is shown in Fig. 1.

\section{Electrochemical Testing and Conversion measurements:}

During the tests the cell stacks were characterized by electrochemical impedance spectroscopy (EIS). The impedance spectra were recorded with a Gamry Reference 600 potentiostat in the frequency range $1 \mathrm{MHz}$ to $0.001 \mathrm{~Hz}$ with 6 points pr. decade and $36 \mathrm{mV}$ rms amplitude. The Gamry Reference 600 potentiostat was also used for polarisation of the cells during the conversion measurements. During the experiments the outlet gas from the cell stack was constantly monitored. The $\mathrm{NO}$ and $\mathrm{NO}_{2}$ concentrations were monitored by a chemiluminiscense detector Model 42i High Level from Thermo Scientific, while the $\mathrm{N}_{2}, \mathrm{~N}_{2} \mathrm{O}$ and $\mathrm{O}_{2}$ concentrations were monitored with a mass spectrometer from Pfeiffer Vacuum, type Omnistar GSD 301SEM. In total five cell stacks were tested, two non-impregnated stacks named N1 and N2, and three $\mathrm{BaO}$-impregnated stacks named B1, B2 and B3.

\section{Test conditions}

The conversion measurements were made at the flow rate $2 \mathrm{~L} / \mathrm{h}$ in $1000 \mathrm{ppm} \mathrm{NO}$ and $1000 \mathrm{ppm} \mathrm{NO}+10 \% \mathrm{O}_{2}$ in both cases with balance Ar. These concentrations of $\mathrm{NO}$ and $\mathrm{O}_{2}$ were chosen as they resemble the concentrations which may be found in the exhaust from a diesel $\mathrm{car}^{24}$. It should be noted, that 1000 ppm $\mathrm{NO}+10 \% \mathrm{O}_{2}$ are the concentrations set during the experiments, while in reality the gas composition will contains some $\mathrm{NO}_{2}$ due to the equilibrium $\mathrm{NO}+1 / 2 \mathrm{O}_{2} \leftrightarrows \mathrm{NO}_{2}$.

Moreover impedance measurements were recorded in $10 \% \mathrm{O}_{2}$ with balance Ar for comparison to impedance spectra recorded in NO containing atmospheres. The experiments were carried out in the temperature range $300-500{ }^{\circ} \mathrm{C}$ which is close to the expected temperature of diesel engine

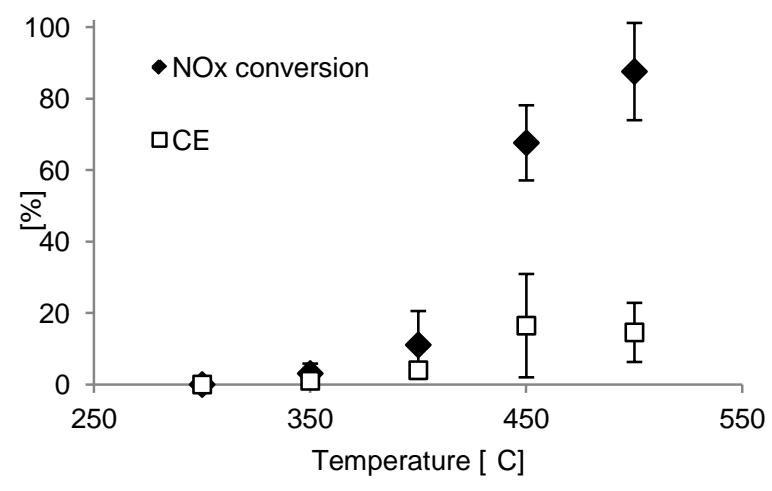

Fig. 2 Percentage of $\mathrm{NO}_{x}$ converted into $\mathrm{N}_{2}$ and the current efficiency (CE) during $3 \mathrm{~V}$ polarisation for $2 \mathrm{~h}$ in $1000 \mathrm{ppm} \mathrm{NO}$ on a $\mathrm{BaO}$ impregnated cell stack. 


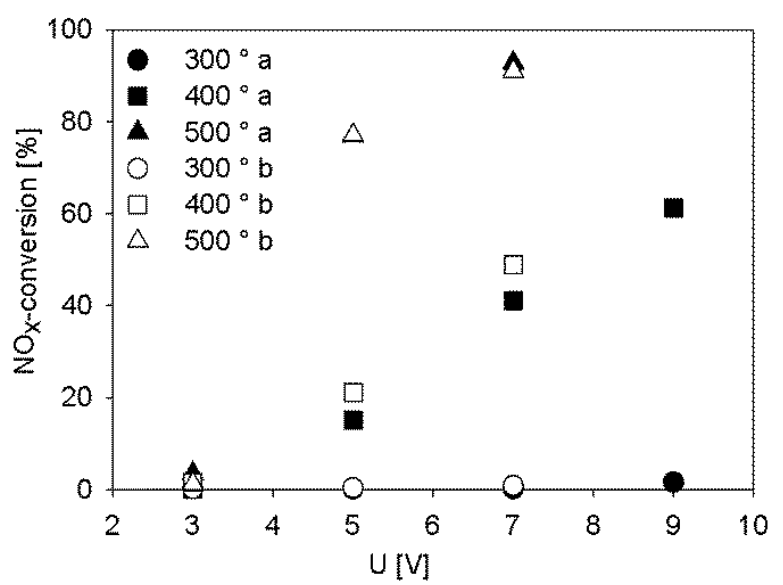

Fig. 3 Percentage of $\mathrm{NO}_{x}$ converted into $\mathrm{N}_{2}$ during polarisation for $2 \mathrm{~h}$ in $1000 \mathrm{ppm} \mathrm{NO}+10 \% \mathrm{O}_{2}$ on a $\mathrm{BaO}$ impregnated cell stack. Closed symbols labelled a were recorded during the stepwise voltage increase from 3 to $9 \mathrm{~V}$, while open symbols labelled $\mathrm{b}$ were recorded during the subsequent voltage decrease from $9 \mathrm{~V}$ to $3 \mathrm{~V}$.

exhaust of $100-400{ }^{\circ} \mathrm{C}^{25}$. Polarisation experiments were made in the range 3-9 V. As each 11 layer cell stacks contain 5 “cells”, the polarisation range pr. cell was $0.6-1.8 \mathrm{~V}$.

\section{SEM}

Before and after testing the cell stacks were examined in a Zeiss Supra 35 scanning electron microscope equipped with a field emission gun. In order to obtain high magnification images of the electrode microstructure images were recorded with the inlens detector and $3 \mathrm{keV}$ acceleration voltage on cells just broken and put directly into the microscope.

\section{Results}

\section{Conversion and current efficiency}

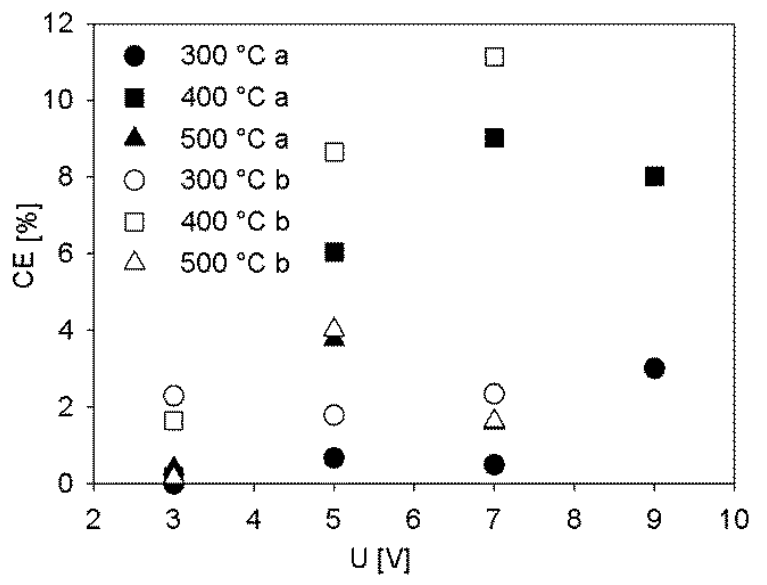

Fig. 4 Current efficiency for conversion of $\mathrm{NO}_{x}$ into $\mathrm{N}_{2}$ during polarisation for $2 \mathrm{~h}$ in $1000 \mathrm{ppm} \mathrm{NO}+10 \% \mathrm{O}_{2}$ on a $\mathrm{BaO}$ impregnated cell stack. Closed symbols labelled a were recorded during the stepwise voltage increase from 3 to $9 \mathrm{~V}$, while open symbols labelled b were recorded during the subsequent voltage decrease from $9 \mathrm{~V}$ to 3 $\mathrm{V}$.

On the non-impregnated cell stacks no conversion of NO into $\mathrm{N}_{2}$ was observed during $3 \mathrm{~V}$ polarisation in the temperature range $300-500{ }^{\circ} \mathrm{C}$, neither when the cell stacks were supplied with $1000 \mathrm{ppm} \mathrm{NO}+10 \% \mathrm{O}_{2}$ nor when the stacks were supplied with only $1000 \mathrm{ppm}$ NO. However, on the $\mathrm{BaO}$ impregnated cell stacks conversion of $\mathrm{NO}_{\mathrm{x}}$ into $\mathrm{N}_{2}$ was observed both without presence of $\mathrm{O}_{2}$ and in the presence of $10 \% \mathrm{O}_{2}$. In Fig. 2 the results from the conversion measurement without $\mathrm{O}_{2}$ in 1000 ppm $\mathrm{NO}$ on the $\mathrm{BaO}$ impregnated stacks are stated, the results are based on measurements on three different stacks. Fig. 2 shows the $\mathrm{NO}_{\mathrm{x}}$ conversion increases with temperature, and especially from $400{ }^{\circ} \mathrm{C}$ to $450{ }^{\circ} \mathrm{C}$ a significant increase in the conversion is observed from below $20 \%$ to above $60 \%$. A significant increase in the current efficiency is also observed from 400 to $450{ }^{\circ} \mathrm{C}$, as the current efficiency increases from $4 \%$ to $16 \%$.

When the $\mathrm{BaO}$ impregnated cell stacks were supplied with $1000 \mathrm{ppm} \mathrm{NO}+10 \% \mathrm{O}_{2}$ and polarised at $3 \mathrm{~V}$ the $\mathrm{NO}_{\mathrm{x}}$ conversion also increased with temperature, however the average $\mathrm{NO}_{\mathrm{x}}$ conversion achieved at $500{ }^{\circ} \mathrm{C}$ was only $4 \%$ and the corresponding current efficiency only $0.3 \%$.

On one of the $\mathrm{BaO}$ impregnated cell stacks the influence of varying the polarisation between $3 \mathrm{~V}, 5 \mathrm{~V}, 7 \mathrm{~V}$ and $9 \mathrm{~V}$ was investigated at $300{ }^{\circ} \mathrm{C}, 400{ }^{\circ} \mathrm{C}$ and $500{ }^{\circ} \mathrm{C}$. At each temperature the first measurements was made at $3 \mathrm{~V}$ whereafter the voltage was increased stepwise till $9 \mathrm{~V}$ was reached, each time with the voltage kept at the specified value for one hour, with a one hour break at OCV in between. After $9 \mathrm{~V}$ had been reached the measurements at $7 \mathrm{~V}, 5 \mathrm{~V}$ and $3 \mathrm{~V}$ were repeated while going down in voltage. The results for the $\mathrm{NO}_{\mathrm{x}}$ conversion are shown in Fig. 3 and for the current efficiency in Fig. 4. With respect to the $\mathrm{NO}_{\mathrm{x}}$-conversion, only a negligible effect of increasing the voltage is observed at $300^{\circ} \mathrm{C}$, where the $\mathrm{NO}_{\mathrm{x}}$ conversion only 


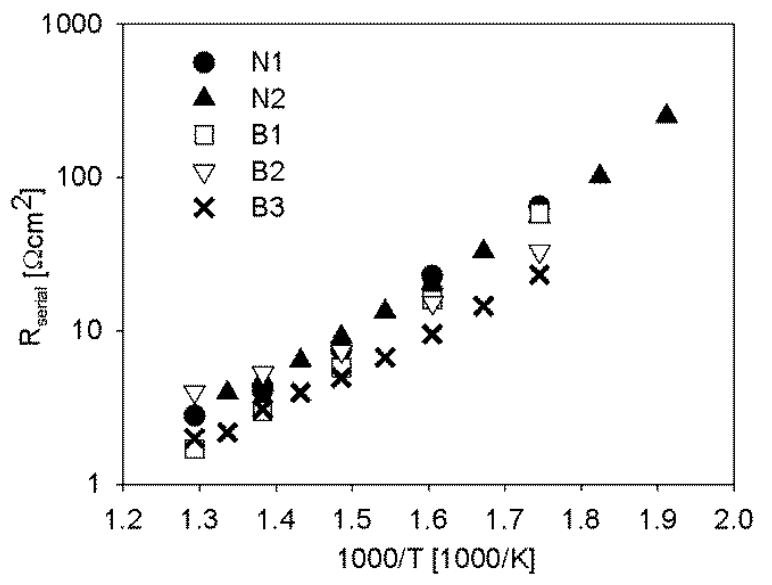

Fig. 5 Arrhenious plot of the serial resistance obtained from fitting of impedance spectra recorded in $1000 \mathrm{ppm} \mathrm{NO}+10 \% \mathrm{O}_{2}$ on nonimpregnated ( $\mathrm{N} 1$ and $\mathrm{N} 2$ ) and $\mathrm{BaO}$-impregnated (B1, B2 and $\mathrm{B} 3$ ) cell stacks.

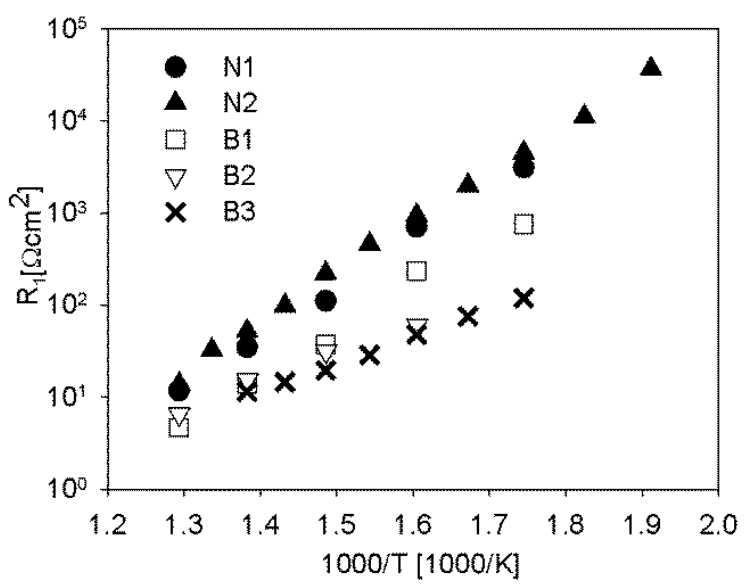

Fig. 6 Arrhenious plot of the high frequency process resistance obtained from fitting of impedance spectra recorded in $1000 \mathrm{ppm}$ NO $+10 \% \mathrm{O}_{2}$ on non-impregnated ( $\mathrm{N} 1$ and $\mathrm{N} 2$ ) and BaO-impregnated (B1, $\mathrm{B} 2$ and B3) cell stacks.

increased from $0 \%$ at $3 \mathrm{~V}$ to $2 \%$ at $-9 \mathrm{~V}$. Contrary to this a distinct effect is observed from increasing the voltage at 400 ${ }^{\circ} \mathrm{C}$, where the $\mathrm{NO}_{\mathrm{x}}$ conversion increased from $0 \%$ at $3 \mathrm{~V}$ to $61 \%$ at $9 \mathrm{~V}$. Moreover an activation effect is observed at $400{ }^{\circ} \mathrm{C}$ on both $\mathrm{NO}_{\mathrm{x}}$-conversion and current efficiency, as both had increased when the measurements at $7 \mathrm{~V}, 5 \mathrm{~V}$ and $3 \mathrm{~V}$ were repeated during the second half of experiment. For comparison a similar polarisation experiment was made at $400{ }^{\circ} \mathrm{C}$ on a nonimpregnated cell stack, but no formation of $\mathrm{N}_{2}$ was observed not

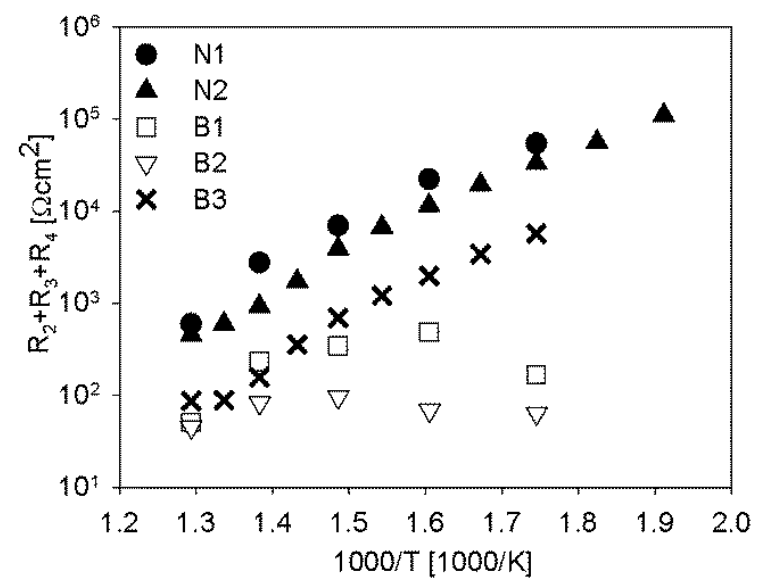

Fig. 7 Arrhenious plot of the sum of the low frequency processes resistance. The resistances were obtained from fitting of impedance spectra recorded in $1000 \mathrm{ppm} \mathrm{NO}+10 \% \mathrm{O}_{2}$ on non-impregnated ( $\mathrm{N} 1$ and $\mathrm{N} 2$ ) and $\mathrm{BaO}$-impregnated (B1, B2 and B3) cell stacks.

even at $9 \mathrm{~V}$ polarisation. At $500^{\circ} \mathrm{C}$ a distinct effect is again observed from increasing the voltage on the $\mathrm{BaO}$-impregnated stack, the relative largest increase in $\mathrm{NO}_{\mathrm{x}}$ conversion per voltage increase is observed when the voltage is increased from $3 \mathrm{~V}$ to $5 \mathrm{~V}$, which makes the $\mathrm{NO}_{\mathrm{x}}$ conversion increase from $4 \%$ to $93 \%$. The measurement at $9 \mathrm{~V}$ is missing at $500{ }^{\circ} \mathrm{C}$, as the corresponding current exceeded the maximum current of the Gamry Ref 600 Potentiostat and the experiment for this reason was interrupted. In general with respect to the current efficiencies they appear to be more or less independent on the voltage at $300{ }^{\circ} \mathrm{C}$ and $500{ }^{\circ} \mathrm{C}$ and do in no cases exceed $5 \%$, whereas at $400{ }^{\circ} \mathrm{C}$ the current efficiencies clearly increase with voltage until $7 \mathrm{~V}$, where it reaches a maximum value of $\approx 10 \%$.

\section{Deconvolution of impedance spectra}

The impedance spectra recorded on the non-impregnated and the BaO-impregnated cell stack were all fitted with a serial resistance and a series connection of 3-4 sub circuits, each sub circuit containing a resistance and a constant phase-element in parallel. In general the process located at the highest frequencies was clearly separable from the lower frequency processes, which on the other hand were strongly overlapping in the impedance spectra. Due to the strong overlap in the low frequency region it was not possible to obtain a linear Arrhenious plot for the individual resistances in this frequency region. To enlighten the processes in the low frequency region the sum of the low frequency resistances $\left(R_{2}, R_{3}\right.$ and in some cases $R_{4}$ ) were instead plottet together. The Arrhenious plot of the serial resistance, $R_{1}$ and $R_{2}+R_{3}+R_{4}$ are shown in Fig. 5, Fig. 6 and Fig. 7 respectively. 


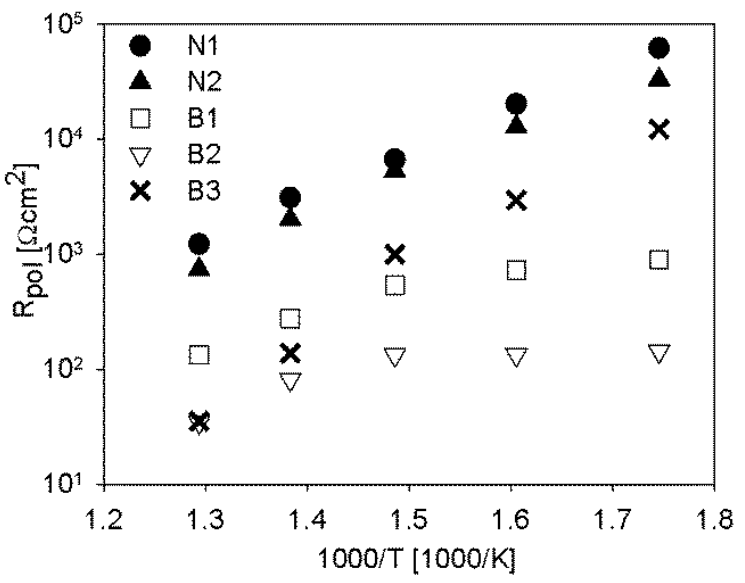

Fig. 8 Polarisation resistance of non-impregnated and impregnated cell stacks in $10 \% \mathrm{O}_{2}$

The serial resistance of the two non-impregnated cell stacks are in almost exact agreement, which is also the case for the resistance of the high frequency process $\left(\mathrm{R}_{1}\right)$ and the low frequency processes $\left(R_{2}+R_{3}+R_{4}\right)$. This means good reproducibility is obtained for the non-impregnated cell stacks. The serial resistances of the $\mathrm{BaO}$-impregnated cell stacks are very close to those of the non-impregnated, however with a tendency to be slightly lower. For the high frequency process the serial resistance is consequently lower for the impregnated cell stacks, the difference between non-impregnated and impregnated stacks being largest at low temperatures. For the low frequency processes some discrepancy is observed between the impregnated stacks, but in all cases the low frequency resistances are lower on the $\mathrm{BaO}$-impregnated stacks compared to non-impregnated. One of the impregnated stacks (B3) shows an activation energy in the low frequency region similar to the activation energy of the non-impregnated stacks. The two other impregnated stacks show in the low frequency region a quite different behaviour, as the resistance show very little temperature dependency. At the highest measured temperature $\left(500{ }^{\circ} \mathrm{C}\right)$, the resistance of all the impregnated cell stacks are quite equal.

For comparison to the just described resistances in the cell stack in $1000 \mathrm{ppm} \mathrm{NO}+10 \% \mathrm{O}_{2}$, the total polarisation resistance in non- and $\mathrm{BaO}$-impregnated cell stacks subjected to only $10 \% \mathrm{O}_{2}$ is shown in Fig. 8. A decrease in the polarisation resistance on the impregnated stacks similar to the one observed in $1000 \mathrm{ppm} \mathrm{NO}+10 \% \mathrm{O}_{2}$ is also observed in $10 \% \mathrm{O}_{2}$. This indicates the $\mathrm{BaO}$ impregnation cause a general increase in the activity of the electrodes.

\section{Characteristics of processes}

In addition to the impedance spectra recorded during temperature variations impedance spectra were also recorded during variation

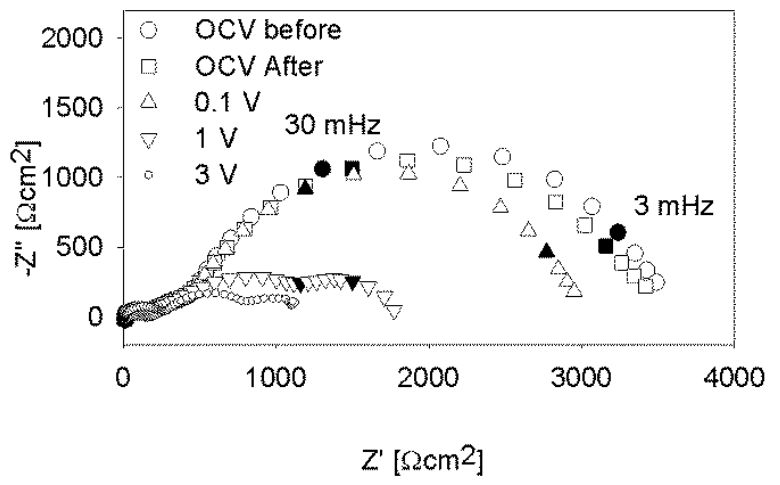

Fig. 9. Impedance spectra recorded on non-impregnated cell stack at $\mathrm{OCV}$ and during polarisation. The stack was at $400{ }^{\circ} \mathrm{C}$ and supplied with $1000 \mathrm{ppm} \mathrm{NO}+10 \% \mathrm{O}_{2}$. The stated frequencies are marked with closed symbols. The spectra labelled "OCV before" and "OCV after" refers are impedance spectra recorded at OCV immediately before and after impedance spectra were recorded under current load.

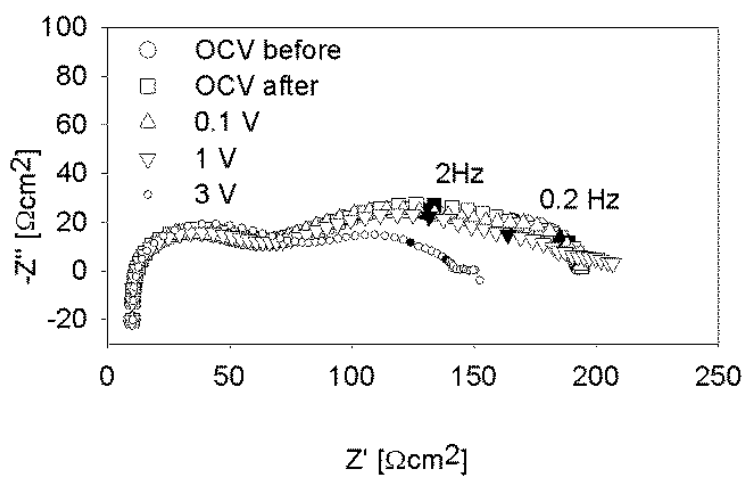

Fig. 10 Impedance spectra recorded on $\mathrm{BaO}$-impregnated cell stack at $\mathrm{OCV}$ during polarisation. The stack was at $400{ }^{\circ} \mathrm{C}$ and supplied with $1000 \mathrm{ppm} \mathrm{NO}+10 \% \mathrm{O}_{2}$. The stated frequencies are marked with closed symbols. The spectra labelled "OCV before" and "OCV after" refers are impedance spectra recorded at OCV immediately before and after impedance spectra were recorded under current load.

in gas composition, flow rate and polarisation. For the concentration variations the "standard" gas composition 1000 ppm $\mathrm{NO}+10 \% \mathrm{O}_{2}$ was varied first by changing the NO content to $1500 \mathrm{ppm}$ and to $500 \mathrm{ppm}$ while keeping $\mathrm{pO}_{2}$ constant, whereafter the NO concentration was fixed at $1000 \mathrm{ppm}$ NO 
while $\mathrm{pO}_{2}$ was changed to $5 \%$ and $15 \%$. These experiments were repeated at several temperatures on the cell stacks. During flow variations the standard flow $2 \mathrm{~L} / \mathrm{h}$ was increased to $2.5 \mathrm{~L} / \mathrm{h}$ and $3 \mathrm{~L} / \mathrm{h}$. The majority of the reported impedance spectra were recorded at $\mathrm{OCV}$, but at $400{ }^{\circ} \mathrm{C}$ a series of impedance spectra were recorded under $0.1 \mathrm{~V}, 1 \mathrm{~V}$ and $3 \mathrm{~V}$ polarisation on both the non- and the $\mathrm{BaO}$-impregnated stacks. From the impedance spectra recorded at different conditions different characteristics could be found for the processes contributing to the polarisation resistance. These characteristics are listed for the nonimpregnated stacks in Table 1 and for the BaO-impregnated stacks in Table 2. It should be noted the characteristics are stated for the 3 dominating processes observed at all temperatures, while a fourth process occasionally appearing at $500{ }^{\circ} \mathrm{C}$ is not included. In addition to the process characteristics listed in the tables the impedance spectra recorded during polarisation on the non-impregnated stack and $\mathrm{BaO}$ impregnated stack are shown in Fig. 9 and Fig. 10 respectively, and show a profound change in the low frequency region during polarisation.

\section{Degradation}

On all the cell stacks an impedance spectrum was recorded at $300{ }^{\circ} \mathrm{C}$ in $1000 \mathrm{ppm} \mathrm{NO}+10 \% \mathrm{O}_{2}$ at the very beginning of the test and at the end of the test, i.e. after the temperature variations, polarisation experiments etc, had been performed. From these spectra the serial and polarisation resistances were determined (Table 3 ) and the percentage change in $\mathrm{R}_{\mathrm{s}}, \mathrm{R}_{1}$ and $\mathrm{R}_{2}+\mathrm{R}_{3}+\mathrm{R}_{4}$ during the cell tests was calculated (Table 4 ). The non-impregnated cell stacks and one of the $\mathrm{BaO}$ impregnated cell stacks (B3) activated during the cell test, as both $R_{s}, R_{1}$ and $\mathrm{R}_{2}+\mathrm{R}_{3}+\mathrm{R}_{4}$ decreased. A decrease in $\mathrm{R}_{\mathrm{s}}$ indicates an improved electric contact through the cell stack, but as the percentage change in the polarisation resistance differs from the percentage change in the serial resistances, improved contact cannot solely explain the changes observed in the polarisation resistances. The two $\mathrm{BaO}$ impregnated cell stacks, which had the lowest polarisation resistance in the beginning of the test (B1 and B2), degraded during the test which caused a large increase in the resistance of the low frequency processes, while $R_{s}$ and $R_{1}$ decreased during the tests decreased as for the other cell stacks. It is worth noticing, that even though the $\mathrm{BaO}$ impregnated cell stacks have a very different initial performance and degradation behaviour, they all at the end of the cell test have a polarisation resistance significantly below the polarisation resistance of the non-impregnated stacks.

\section{SEM microscopy}

Representative SEM images from the microscopy investigation of the electrodes are shown in Fig. 11. The SEM images of the non-impregnated electrodes before test (Fig. 11, a) show slightly rugged LSM15 grains in between smooth CGO10 grains. No evident differences are observed between the nonimpregnated electrode before test (Fig. 11, a) and after test (Fig. 11, b). On the $\mathrm{BaO}$ impregnated electrodes before test (Fig. 11, c), the impregnated $\mathrm{BaO}$ is clearly visible as distinct particles located on the LSM15 grains. After testing the microstructure of the $\mathrm{BaO}$ impregnated electrodes had clearly changed, and three different kinds of microstructure were observed even within the same cell stack: electrode grains being almost entirely covered by nanometer sized, round and well-defined particles (Fig. 11, d), electrode grains covered in a more "fluffy" structure (Fig. 11, e) and electrode grains covered entirely in flake-like particles (Fig. 11, f). The weight load of $\mathrm{BaO}$ on the cell stacks used for the microscopy was $2 \pm 0.1 \mathrm{wt} \%$, which means differences in microstructure likely cannot be ascribed to differences in $\mathrm{BaO}$ weight load. Furthermore the SEM images showed a similar microstructure of the B1 and the B3 cell stacks, even though these stacks degraded/activated quite differently during the testing.
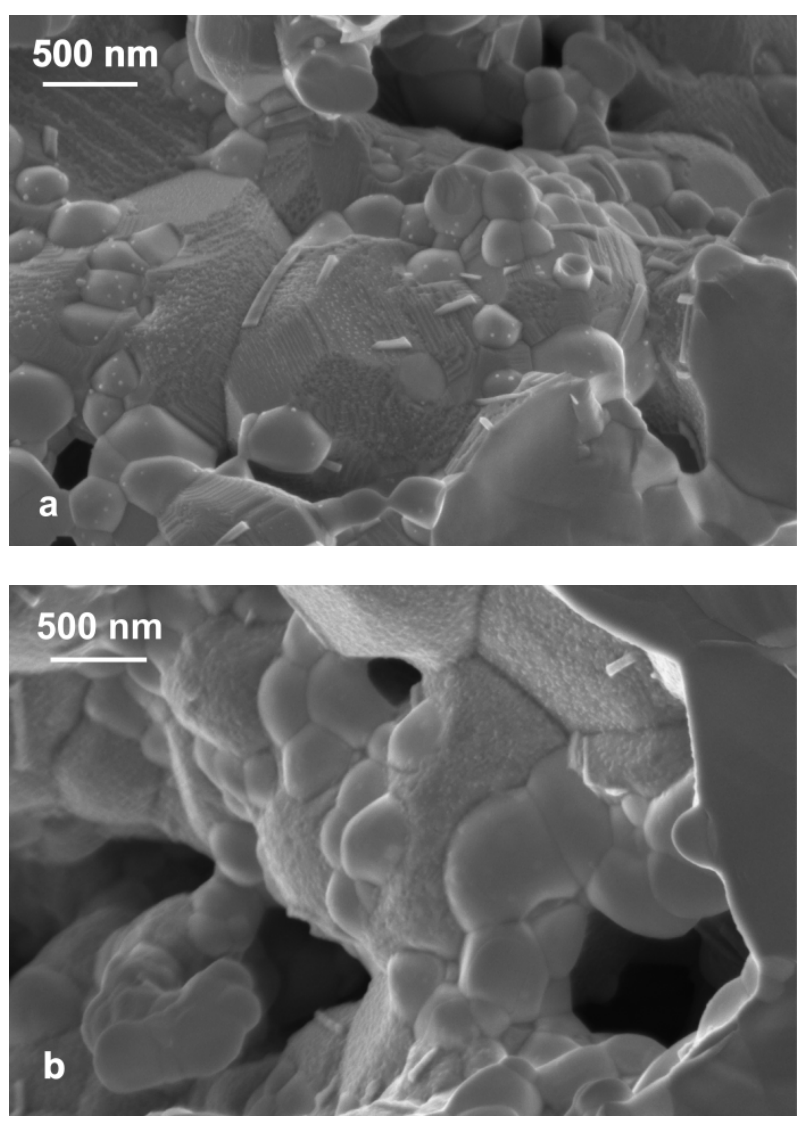

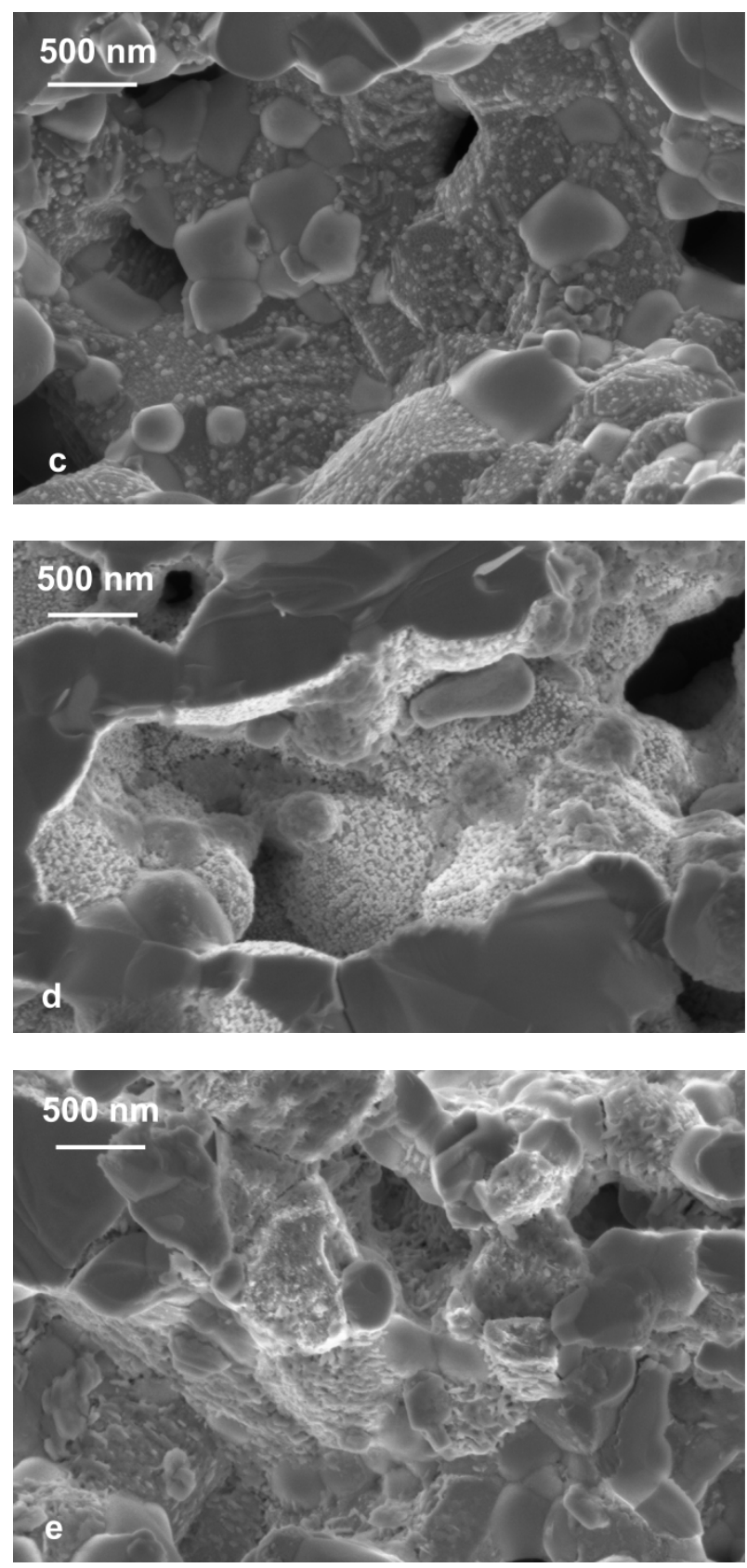

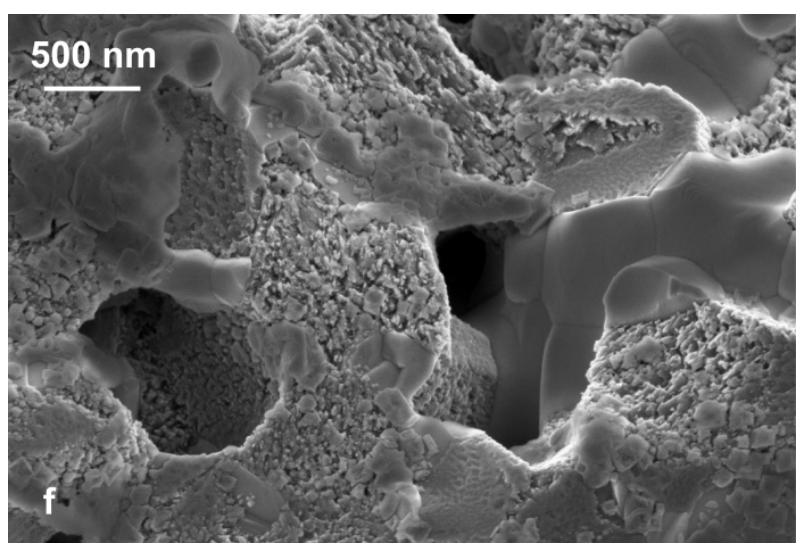

Fig. 11. SEM images of electrodes of the following LSM15-CGO10 cell stacks: a) non-impregnated before test b) non-impregnated after test c) $\mathrm{BaO}$ impregnated before test and d) - f) $\mathrm{BaO}$ impregnated after test.

\section{Discussion}

\section{Processes on non-impregnated electrodes}

Three processes were dominating the polarisation resistance of the non-impregnated electrodes. The high-frequency process was characterized by a temperature independent $\mathrm{C}_{\omega}$ with a value around $1 \cdot 10^{-7} \mathrm{~F} / \mathrm{cm}^{2}$, a resistance independent on atmosphere and an activation energy of $1.08 \pm 0.01 \mathrm{eV}$ in $1000 \mathrm{ppm} \mathrm{NO}+$ $10 \% \mathrm{O}_{2}$. These characteristics are consistent with characteristics reported in literature for processes related to transfer of oxygen ions between the perovskite and the electrolyte ${ }^{26-28}$. For the middle frequency process $\mathrm{R}$ increased with decreasing $\mathrm{pO}_{2}$ which indicate $\mathrm{O}_{2}$ or an $\mathrm{O}$-specie is participating in the middle frequency process. The $\mathrm{C}_{\omega}$ of the middle frequency arc varied in the range $1 \cdot 10^{-5}-1 \cdot 10^{-4} \mathrm{~F} / \mathrm{cm}^{2}$, a range in fairly good agreement with the capacitance associated with adsorption and dissociation of oxygen on composite cathodes ${ }^{29}$. The $\mathrm{C}_{\omega}$ of the middle frequency arc showed a strange behaviour with respect to the temperature dependency as the $\mathrm{C}_{\omega}$ increases from $300{ }^{\circ} \mathrm{C}$ to $400{ }^{\circ} \mathrm{C}$ and decreases from $400{ }^{\circ} \mathrm{C}$ to $500{ }^{\circ} \mathrm{C}$, the observation was made on two different stacks. The best explanation of this observation is the middle frequency process contains contributions from two different processes, which change relative importance with temperature. The low frequency process is characterized by $\mathrm{C}_{\omega}$ increasing with temperature and decreasing $\mathrm{pO}_{2}$, and $\mathrm{R}$ decreasing with polarisation. This is consistent with the low frequency process being dependent on the vacancy concentration of the oxide electrode materials and/or the extension/broadening of the triple phase boundary zone. As the resistance of the low frequency process also increases with decreasing NO concentration, the process is ascribed to a $\mathrm{NO}_{\mathrm{x}}$ specie ( $\mathrm{NO}$ or $\mathrm{NO}_{2}$ ) which is adsorbing, diffusing on the surface or participating in charge-transfer 
related processes at or near the triple phase boundary. The presence of such a process on perovskite/CGO10 electrodes is in good agreement with previous findings in our group ${ }^{28,30}$.

\section{Processes on impregnated electrodes}

The impedance spectra recorded on the BaO-impregnated cell stacks are dominated by three processes. The high frequency process shares several characteristics with the high frequency process observed on the non-impregnated cell stack, namely summit frequency range, a $\mathrm{C}_{\omega}$ around $1 \cdot 10^{-7} \mathrm{~F} / \mathrm{cm}^{2}$ and lack of dependency on gas composition. Therefore the high frequency arc is ascribed to the same process, as it also seems reasonable the process related to transfer of oxygen ions/intermediates between the perovskite and the electrolyte, should be visible for both non-impregnated and impregnated cell stacks. However, Fig. 6 showed the resistance of the high frequency process is consequently lower for the impregnated stacks. The decrease in the resistance could be related to the profound microstructural changes observed in the $\mathrm{BaO}$ impregnated electrodes observed in Fig. 11. The characteristics of the middle frequency arc are $\mathrm{C}_{\omega}$ increasing with temperature and decreasing with decreasing $\mathrm{pO}_{2}$, while $\mathrm{R}$ decreases with polarisation. The difference in characteristics between the non-impregnated and $\mathrm{BaO}-$ impregnated samples makes it less probable the middle frequency process is the same on the two different kinds of cell stacks. Due to the dependency on temperature and polarisation the middle frequency process on the $\mathrm{BaO}$-impregnated stacks is likely due to a triple phase boundary related process, but exactly which process and which species are involved cannot be determined from the available data. Finally the low frequency process on the BaO-impregnated sample show almost identical characteristics with the low frequency process on the nonimpregnated cell stack, the one exception being on the $\mathrm{BaO}-$ impregnated sample the $\mathrm{C}_{\omega}$ also depend on the pNO. Due to the similar characteristics the process is for the $\mathrm{BaO}$-impregnated cell stack also ascribed to triple-phase boundary related adsorption, diffusion and/or charge transfer involving NO or $\mathrm{NO}_{2}$. However, an important difference between the non- and $\mathrm{BaO}$-impregnated samples is the resistance of the process is much smaller on the $\mathrm{BaO}$-impregnated samples, for instance at $500{ }^{\circ} \mathrm{C}$ approximately an order of magnitude smaller compared to the non-impregnated sample. The difference in the low frequency arc resistance to a large extent explains the decreased resistance in the low frequency region of the impregnated samples observed in Fig. 7. It is suggested the decreased resistance of the low frequency process is due to $\mathrm{NO} / \mathrm{NO}_{2}$ getting adsorbed on the $\mathrm{BaO}$ in the form of $\mathrm{Ba}\left(\mathrm{NO}_{3}\right)_{2}$ rather than getting adsorbed on the LSM15 and/or CGO10 as in the non-impregnated cell stack. The implication of the difference in adsorption for the entire electrode process and $\mathrm{NO}_{\mathrm{x}}$-reduction will be discussed in the next section.

\section{Effect of BaO-impregnation on electrode processes and $\mathrm{NO}_{\mathrm{x}}$ conversion}

In the previous two sections the electrode processes on the nonimpregnated and the $\mathrm{BaO}$-impregnated cell stacks were identified and compared and it was suggested the difference in electrode processes in $1000 \mathrm{ppm} \mathrm{NO}+10 \% \mathrm{O}_{2}$ could be explained by $\mathrm{NO}_{\mathrm{x}}$ adsorbing either directly on the LSM15CGO10 or on the $\mathrm{BaO}$. From FTIR studies of $\mathrm{NO}_{\mathrm{x}}$ adsorption it is known that $\mathrm{NO}_{\mathrm{x}}$ at higher temperatures is adsorbed in the form of $\mathrm{NO}_{3}{ }^{-}$, and that the $\mathrm{NO}_{3}{ }^{-}$formation is preceded by either $\mathrm{NO} / \mathrm{O}_{2}$ co-adsorption or $\mathrm{NO}_{2}$ formation and subsequent adsorption, these observations has been made both on CGO10/ceria $^{31}$ and perovskites ${ }^{32}$. Moreover it was shown in the work by Werchmeister et al. that $\mathrm{NO}_{2}$ is an important reaction intermediate in electrochemical $\operatorname{deNO}_{\mathrm{x}}{ }^{28,33}$, considering the findings from FTIR studies this is likely because $\mathrm{NO}_{2}$ must be formed before adsorption/formation of nitrate on the electrode surface can occur, a step which necessarily must preceed the electrochemical reduction. Formation of $\mathrm{NO}_{3}{ }^{-}$from $\mathrm{NO}_{2}$ requires an $\mathrm{O}^{-}$specie according to the reaction scheme $\mathrm{NO}_{2}+\mathrm{O}^{-}$ $\rightarrow \mathrm{NO}_{3}{ }^{-}$(or presence of an adsorbed O-atom and an electron). For the non-impregnated electrode two of the identified processes were one related to $\mathrm{O}_{2}$ adsorption and dissociation (Process 2) and one related to $\mathrm{NO}_{\mathrm{x}}$ adsorption/diffuse/charge transfer at the triple phase boundary (Process 3 ). This is in very good agreement with the expected mechanism, were $\mathrm{O}^{-} / \mathrm{O}$ (ads) needs to be formed (corresponding to Process 2), before $\mathrm{NO}_{3}{ }^{-}$ can be formed and react in the triple phase boundary region (corresponding to Process 3 ). With respect to adsorption of $\mathrm{NO}_{\mathrm{x}}$ on $\mathrm{BaO}$ and formation of $\mathrm{Ba}\left(\mathrm{NO}_{3}\right)_{2}$, this process has been shown by FTIR to proceed fastest with $\mathrm{NO}_{2}{ }^{34}$ even though the exact mechanism of $\mathrm{Ba}\left(\mathrm{NO}_{3}\right)_{2}$ formation is still under discussion ${ }^{35-37}$. The reaction scheme for $\mathrm{Ba}\left(\mathrm{NO}_{3}\right)_{2}$ formation with $\mathrm{NO}_{2}$ is $\mathrm{BaO}+2 \mathrm{NO}_{2}+1 / 2 \mathrm{O}_{2} \rightarrow \mathrm{Ba}\left(\mathrm{NO}_{3}\right)_{2}$ and in NSR catalysis this storage process takes place without involving any electrochemical steps. It is suggested that during electrochemical deNO $\mathrm{N}_{\mathrm{x}}$ the $\mathrm{NO}_{\mathrm{x}}$ storage process also takes place without involving any electrochemical steps. This is supported by the fact that the polarisation resistance on the impregnated cell stack show no dependency on $\mathrm{O}_{2}$ adsorption and dissociation related processes. By combining the results from the impedance analysis with the observation from the conversion measurements, which showed increased $\mathrm{NO}_{\mathrm{x}}$ conversion on $\mathrm{BaO}$ impregnated cell stacks, it becomes likely that the increased $\mathrm{NO}_{\mathrm{x}}$ conversion at least to some extent is due to the adsorption on $\mathrm{BaO}$ rather than on LSM15-CGO10, which establishes an easier reaction path for the electrochemical reduction of $\mathrm{NO}_{\mathrm{x}}$ in the cell stacks. The suggestion, that the $\mathrm{NO}_{\mathrm{x}}$ adsorption on the $\mathrm{BaO}$ impregnated cell stack proceeds via a route only dependent on $\mathrm{O}_{2}(\mathrm{~g})$ and not electrochemically 
enhanced $\mathrm{O}_{2}$ adsorption/dissociation, does however not explain the increased $\mathrm{NO}_{\mathrm{x}}$ conversion in 1000 ppm NO without oxygen. A detailed impedance analysis was not carried out in $1000 \mathrm{ppm}$ $\mathrm{NO}$, as the very low oxygen partial pressure in $1000 \mathrm{ppm}$ NO alters the stochiometry of the oxide electrode materials during time and this instability hinders a reasonable interpretation of the impedance spectra. However, the increased $\mathrm{NO}_{\mathrm{x}}$ conversion in 1000 ppm NO could be explained by the general increase in electrode activity caused by the $\mathrm{BaO}$-impregnation. In the results section it was also shown the $\mathrm{BaO}$-impregnation in general caused an increased electrode activity, as the BaOimpregnation also decreased the polarisation resistance in 10\% $\mathrm{O}_{2}$, which is in agreement with the reportings on $\mathrm{BaO}$ containing cathodes being superior in activity to conventional LSM15 cathodes. Therefore it can from this work be concluded, that impregnation with $\mathrm{BaO}$ definitely increases the $\mathrm{NO}_{\mathrm{x}}$-conversion on LSM15-CGO10 cathodes, but whether the increased conversion in $1000 \mathrm{ppm} \mathrm{NO}+10 \% \mathrm{O}_{2}$ mainly is caused by a change in adsorption state or by a general increase in electrode activity remains an unanswered question.

\section{Degradation/activation behaviour of cell stacks related to microstructural changes}

The SEM images showed profound changes in the microstructure of the $\mathrm{BaO}$-impregnated cell stacks after testing. The microstructure appeared similar between cell stacks even though they degraded/activated differently during testing. Moreover the images clearly showed areas with different microstructure, which were characterized by 1) Round and well-defined particles, 2) "Fluffy" structure and 3) Flake-like particles. Eventually the differences in microstructure could be different stages of the same process going on the electrodes. A possible explanation of the microstructural changes could be the $\mathrm{BaO}$ may react with the electrode materials, LSM15 and/or CGO10, and form new compounds. A possible compound could be $\mathrm{BaCeO}_{3}$ or $\mathrm{BaCe}_{1-\mathrm{x}} \mathrm{Gd}_{\mathrm{x}} \mathrm{O}_{\mathrm{y}}$, however it is hard from literature to estimate the risk for $\mathrm{BaCeO}_{3}$ formation. In many studies CGO is used as electrolyte in connection with Ba-containing cathodes and none of the studies report $\mathrm{BaCeO}_{3}$ formation below $900{ }^{\circ} \mathrm{C}^{38-40}$, however the aforementioned studies only consider the temperature effect on material stability and do not consider the effect of polarisation. With respect to the LSM studies some studies indicate there will be no reaction between Ba-containing compounds and LSM ${ }^{41,42}$ while the work by Yang et al. show Ba diffusing from $\mathrm{Ba}_{0.5} \mathrm{Sr}_{0.5} \mathrm{Co}_{0.8} \mathrm{Fe}_{0.2} \mathrm{O}_{3-\delta}$ into $\mathrm{LSM}^{43}$. In conclusion further microstructural and elemental analysis must be conducted to investigate, if cations have migrated and/or new phases have formed in the $\mathrm{BaO}$ impregnated samples in this work.

\section{Conclusion}

The electrochemical conversion of $\mathrm{NO}_{\mathrm{x}}$ on non-impregnated and $\mathrm{BaO}$-impregnated LSM15-CGO10 porous cell stacks has been investigated, and extensive impedance analysis have been performed to identify the effect of the $\mathrm{BaO}$ on the electrode processes. Non-impregnated LSM15-CGO10 cell stacks were not capable of converting $\mathrm{NO}_{\mathrm{x}}$ into $\mathrm{N}_{2}$ at any of the investigated conditions (300-500 ${ }^{\circ} \mathrm{C}$, $3 \mathrm{~V}-9 \mathrm{~V}$ polarisation, $1000 \mathrm{ppm} \mathrm{NO}$ or $1000 \mathrm{ppm} \mathrm{NO}+10 \% \mathrm{O}_{2}$ ). In contrast $\mathrm{BaO}$ impregnated cell stacks could convert $\mathrm{NO}_{\mathrm{x}}$ to $\mathrm{N}_{2}$, even in the presence of $10 \%$ $\mathrm{O}_{2}$, which shows $\mathrm{NO}_{\mathrm{x}}$ conversion can be achieved in an entirely ceramic, noble metal-free electrochemical cell. The $\mathrm{NO}_{\mathrm{x}}$ conversion to $\mathrm{N}_{2}$ on the impregnated stacks was significantly enhanced when the temperature was increased from $300{ }^{\circ} \mathrm{C}$ to $400{ }^{\circ} \mathrm{C}$ or higher, and when the polarisation was increased from $3 \mathrm{~V}$ to $5 \mathrm{~V}$ or higher. The impedance analysis revealed that the BaO-impregnation both increased the overall activity of the cell stacks and also changed the adsorption state of $\mathrm{NO}_{\mathrm{x}}$ on the electrodes, which of the effects are mainly responsible for the increased $\mathrm{NO}_{\mathrm{x}}$ conversion remains unknown. The $\mathrm{BaO}-$ impregnated cell stacks showed a profound change in microstructure after testing, the cause of this change needs to be investigated further.

\section{Acknowledgement}

This work was supported by the Danish Strategic Research Council under contract no. 09-065183. Colleagues at the Fuel Cell and Solid State Chemistry Division, Technical University of Denmark, are thanked for help and fruitful discussions.

\section{Notes and references}

Department of Energy Conversion and Storage, Technical University of Denmark, Frederiksborgvej 399, DK-4000 Roskilde, Denmark. Fax:+45 4677 5858; Tel: +45 2132 7937; E-mail: matr@dtu.dk

References

1 European Environment Agency, Www. Eea. Europa. Eu, (accessed 22/12, 2011), .

2 K. Wark, C. F. Warner and W. T. Davis, Air Pollution its Origin and Control, Third Edition, Addison Wesley Longman, Inc., USA, 1998. 
3 K. Skalska, J. S. Miller and S. Ledakowicz, Sci. Total

Environ., 2010, 408, 3976-3989.

4 K. K. Hansen, Appl. Catal. , B, 2010, 100, 427-432.

5 S. Pancharatnam, R. A. Huggins and D. M. Mason, J.

Electrochem. Soc., 1975, 122, 869-875.

6 D. C. Cicero and L. A. Jarr, Sep. Sci. Technol., 1990, 25, 1455-1472.

7 T. Hibino, Chem. Lett., 1994, 5, 927-930.

8 T. Hibino, T. Inoue and M. Sano, Solid State Ionics, 2000, 130, 19-29.

9 K. Hamamoto, Y. Fujishiro and M. Awano, J. Electrochem. Soc., 2008, 155, E109-E111.

10 K. Hamamoto, T. Suzuki, Y. Fujishiro and M. Awano, J. Electrochem. Soc., 2011, 158, B1050-B1053.

11 S. Bredikhin, K. Maeda and M. Awano, Solid State Ionics, 2001, 144, 1-9.

12 K. J. Walsh and P. S. Fedkiw, Solid State Ionics, 1996, 93, $17-31$.

13 R. M. L. Werchmeister, K. K. Hansen and M. Mogensen, Mater. Res. Bull., 2010, 45, 1554-1561.

14 W. S. Epling, L. E. Campbell, A. Yezerets, N. W. Currier and J. E. Parks, Catal. Rev. Sci. Eng., 2004, 46, 163-245.
15 X. Li and P. Vernoux, Appl. Catal. , B, 2005, 61, 267-273.

16 Y. Yoshinobu , Y. Tsuda, H. Ueda, Y. Nakanishi and J. Gong , SAE Int.J.Fuels Lubr., 2010, 3, 50-60.

17 V. L. E. Simonsen, M. M. Johnsen and K. K. Hansen, Top. Catal., 2007, 45, 131-135.

18 C. W. Sun, R. Hui and J. Roller, J. Solid State Electrochem., 2010, 14, 1125-1144.

19 B. Dalslet, P. Blennow, P. V. Hendriksen, N. Bonanos, D. Lybye and M. Mogensen, J. of Solid State Electrochem., 2006, 10, 547-561.

20 Z. He, K. Bohm, A. L. Keel, F. B. Nygaard, M. Menon and K. K. Hansen, Ionics, 2009, 15, 427-431.

21 S. Gordon and C. Campbell, Anal. Chem., 1955, 27, 11021109.

22 F. Lazarini and B. S. Brcic, Monatshefte Fur Chemie Und Verwandte Teile Anderer Wissenschaften, 1966, 97, 1318-\&.

23 A. L. Kustov and M. Makkee, Appl. Catal. , B, 2009, 88, 263-271.

24 J. Kaspar, P. Fornasiero and N. Hickey, Catal. Today, 2003, 77, 419-449.

25 K. Adams, J. Cavataio and R. Hammerle, Appl. Catal. , B, 1996, 10, 157-181. 
26 E. Murray, T. Tsai and S. Barnett, Solid State Ionics, 1998, 110, 235-243.

27 M. J. Jørgensen and M. Mogensen, J. Electrochem. Soc., 2001, 148, A433-A442.

28 R. M. L. Werchmeister, K. K. Hansen and M. Mogensen, J. Electrochem. Soc., 2010, 157, P35-P42.

29 E. Barsoukov and J. R. Macdonald, Impedance Spectroscopy Theory, Experiment and Applications, Second Edition, John Wiley and Sons, Inc., Hoboken, New Jersey, 2005.

30 M. L. Traulsen and K. K. Hansen, Accepted for Publication in J. of Solid State Electrochem. DOI 10. 1007/s10008012-1684-9, 2011, .

31 S. Philipp, A. Drochner, J. Kunert, H. Vogel, J. Theis and E. Lox, Top. Catal., 2004, 30-31, 235-238.

32 J. Liu, Z. Zhao, C. Xu, A. Duan and G. Jiang, J. Phys. Chem. C, 2008, 112, 5930-5941.

33 R. M. L. Werchmeister, K. K. Hansen and M. Mogensen, J. Electrochem. Soc., 2010, 157, P107-P112.

34 M. O. Symalla, A. Drochner, H. Vogel, S. Philipp, U. Gobel and W. Muller, Top. Catal., 2007, 42-43, 199-202.

35 B. Westerberg and E. Fridell, J. Mol. Catal A: Chem., 2001, 165, 249-263.
36 F. Prinetto, G. Ghiotti, I. Nova, L. Lietti, E. Tronconi and P. Forzatti, J. Phys. Chem. B, 2001, 105, 12732-12745.

37 Y. Ji, T. J. Toops, J. A. Pihl and M. Crocker, Appl. Catal. , B, 2009, 91, 329-338.

38 H. Zhao, D. Teng, X. Zhang, C. Zhang and X. Li, J. Power Sources, 2009, 186, 305-310.

39 J. H. Kim, M. Cassidy, J. T. S. Irvine and J. Bae, J. Electrochem. Soc., 2009, 156, B682-B689.

40 A. Rolle, N. Preux, G. Ehora, O. Mentre and S. DavieroMinaud, Solid State Ionics, 2011, 184, 31-34.

41 N. Ai, S. P. Jiang, Z. Lue, K. Chen and W. Su, J. Electrochem. Soc., 2010, 157, B1033-B1039.

42 C. Jin, J. Liu and J. Sui, J. Electroceram., 2011, 26, 74-77.

43 M. Yang, M. Zhang, A. Yan, M. Yue, Z. Hou, Y. Dong and M. Cheng, J. Power Sources, 2008, 185, 784-789. 


\section{Tables}

Table 1. Characteristics of processes contributing to the impedance spectra recorded on non-impregnated cell stacks in an atmosphere containing 500-1500 ppm NO and 5-15\% $\mathrm{O}_{2}$ within the temperature range $300-500{ }^{\circ} \mathrm{C}$.

\begin{tabular}{|c|c|c|}
\hline Process & Freq. range & Characteristic $^{*}$ \\
\hline 1 & $300-80000 \mathrm{~Hz}$ & - $\mathrm{C}_{\omega}$ temperature independent \\
\hline 2 & $0.5-25 \mathrm{~Hz}$ & $\begin{array}{l}\text { - } \mathrm{C}_{\omega} \text { increases from } 300 \text { to } 400{ }^{\circ} \mathrm{C} \text {, then decreases to } 500{ }^{\circ} \mathrm{C} \\
-\mathrm{C}_{\omega} \text { dependent on } \mathrm{pO}_{2} \text { (increase with decreasing } \mathrm{pO}_{2} \text { ) } \\
\text { - } \mathrm{R} \text { dependent on } \mathrm{pO}_{2} \text { (increase with decreasing } \mathrm{pO}_{2} \text { ) }\end{array}$ \\
\hline 3 & $0.02-0.5 \mathrm{~Hz}$ & $\begin{array}{l}\text { - } \mathrm{C}_{\omega} \text { increases with temperature } \\
-\mathrm{C}_{\omega} \text { dependent on } \mathrm{pO}_{2} \text { (increase with decreasing } \mathrm{pO}_{2} \text { ) } \\
\text { - } \mathrm{R} \text { decreases with polarisation } \\
\text { - } \mathrm{R} \text { dependent on pNO (increase with decreasing pNO) }\end{array}$ \\
\hline
\end{tabular}

* $\mathrm{C}_{\omega}$ is the near-equivalent capacitance of the process 
Table 2. Characteristics of processes contributing to the impedance spectra recorded on Ba-impregnated cell stacks in an atmosphere containing 500-1500 ppm NO and 5-15\% $\mathrm{O}_{2}$ within the temperature range $300-500{ }^{\circ} \mathrm{C}$.

\begin{tabular}{|c|c|c|}
\hline Process & Freq. range & Characteristic \\
\hline 1 & $5000-70000 \mathrm{~Hz}$ & $\begin{array}{l}\text { - } C_{\omega} \text { decreases with temperature (9) or increases with temp. (6) and (7) } \\
\text { - R increases with polarisation }\end{array}$ \\
\hline 2 & $8-40 \mathrm{~Hz}$ & $\begin{array}{l}\text { - } \mathrm{C}_{\omega} \text { increases with temperature } \\
\text { - } \mathrm{C}_{\omega} \text { dependent on } \mathrm{pO}_{2} \text { (decrease with decreasing } \mathrm{pO}_{2} \text { ) } \\
\text { - } \mathrm{R} \text { decreases with polarisation }\end{array}$ \\
\hline 3 & $4 \mathrm{mHz}-0.2 \mathrm{~Hz}$ & $\begin{array}{l}\text { - } \mathrm{C}_{\omega} \text { increases with temperature } \\
-\mathrm{C}_{\omega} \text { dependent on } \mathrm{pO}_{2} \text { (increase with decreasing } \mathrm{pO}_{2} \text { ) } \\
\text { - } \mathrm{C}_{\omega} \text { dependent on pNO (increase with decreasing pNO) } \\
\text { - } \mathrm{R} \text { decreases with polarisation } \\
\text { - } \mathrm{R} \text { dependent on pNO (increase with decreasing pNO) }\end{array}$ \\
\hline
\end{tabular}


Table 3. Serial resistance $\left(R_{s}\right)$ and polarisation resistance $\left(R_{p}\right)$ in $1000 \mathrm{ppm} \mathrm{NO}+10 \% \mathrm{O}_{2}$ at $300{ }^{\circ} \mathrm{C}$ at the start of the test and the end of the test. The values stated for non-impregnated samples are average values for two different tests, the deviation between resistances in the two tests were below $6 \%$.

\begin{tabular}{lcc|cc} 
& \multicolumn{2}{c|}{ Test start } & \multicolumn{2}{c}{ Test end } \\
& $\mathrm{R}_{\mathrm{s}}\left[\Omega \mathrm{cm}^{2}\right]$ & $\mathrm{R}_{\mathrm{p}}\left[\Omega \mathrm{cm}^{2}\right]$ & $\mathrm{R}_{\mathrm{s}}\left[\Omega \mathrm{cm}^{2}\right]$ & $\mathrm{R}_{\mathrm{p}}\left[\Omega \mathrm{cm}^{2}\right]$ \\
\hline Non-impregnated & 67 & 46070 & 48 & 25320 \\
B1 & 60 & 923 & 30 & 1090 \\
B2 & 48 & 110 & 38 & 300 \\
B3 & 68 & 66253 & 44 & 7643 \\
\hline
\end{tabular}


Table 4. Percentage change in serial resistance $\left(R_{s}\right)$, resistance of the high frequency process $\left(R_{1}\right)$ and the sum of the low frequency processes $\left(R_{2}+R_{3}+R_{4}\right)$ between the start and the end of the test. The resistances are obtained from impedance spectra recorded in 1000 ppm $\mathrm{NO}+10 \% \mathrm{O}_{2}$ at $300{ }^{\circ} \mathrm{C}$.

\begin{tabular}{lccc} 
& $\mathrm{R}_{\mathrm{s}}$ & $\mathrm{R}_{1}$ & $\mathrm{R}_{2}+\mathrm{R}_{3}+\mathrm{R}_{4}$ \\
\hline Non-impregnated & -29 & -91 & -39 \\
B1 & -50 & -83 & 477 \\
B2 & -20 & -30 & 5277 \\
B3 & -36 & -96 & -88 \\
\hline
\end{tabular}

